\title{
Basic Study on Moving Body in Narrow Passage Considering Nonlinearity of Actuator
}

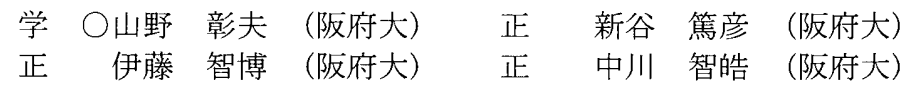

Akio YAMANO, Osaka Prefecture University, 1-1, Gakuen-cho, Naka-ku, Sakai, Osaka

Atsuhiko SHINTANI, Osaka Prefecture University

Tomohiro ITO, Osaka Prefecture University

Chihiro NAKAGAWA, Osaka Prefecture University

\section{1 緒 言}

人間が立ち入ることの困難な流体で満たされた細管内の 調査において，無人機の投入は有効な手段である。このよ うな空間での推進において，流体力を用いた推進が有効で あると考えられる。このような推進方法に関して，魚のよ うな鯺を用いた推進機構は静寂性や推進効率の面で優れて いると言われている(1).そこで今回は形状記憶合金(Shape memory alloy: SMA)アクチュエータを用い小型化・軽量化 が容易な推進機構のモデル化・評価を行うこととした。

\section{2 解析モデルの構築}

\section{$2 \cdot 1$ 推進体の製作と駆動方法}

今回製作した推進体のプロトタイプをFig. 1に示す. 駆動 方法においては, 柔軟な周波数変更を達成する試みとして 自励駆動法 ${ }^{(2)}$ 用いることとし，これを行うにあたって SMA アクチュエータの相変化に伴う抵抗值の変化を観測 し移動平均をとった上でフィードバックに用いることとし た.これより，移動平均のデータ数を逐次変更させること で系全体の固有振動数が変化し，発振周波数を柔軟に調整 できることが期待される。

尾部の構成は SMA アクチュエータの内蔵された駆動部 と柔軟な鯺を備えた受動部で構成し, 推進効率の向上に努 める.

\section{$2 \cdot 2$ 解析モデルの構筑}

最適化を行う場合などでは数理解析的なモデルの構築が 有効である. しかし魚のような推進機構の研究において, 流路壁面の効果までを考慮したものはほとんど見られない. そこで本研究では, 類似した解析条件での流動励起振動の 解析モデル(3)を参考とすることにする.

Fig. 2のような推進体の支配方程式は, 不連続断面の梁モ デルとして次のように表せる.

$$
\begin{aligned}
& \rho_{m}(X) A(X) \frac{\partial^{2} H(X, T)}{\partial T^{2}}+\frac{\partial^{2}}{\partial X^{2}}\left\{\eta I(X) \frac{\partial^{3} H(X, T)}{\partial T \partial X^{2}}\right\} \\
& +\frac{\partial^{2}}{\partial X^{2}}\left\{E I(X) \frac{\partial^{2} H(X, T)}{\partial X^{2}}\right\}=B(X)\left\langle[\Delta P](X, T)+\frac{\partial^{2} M(X, T)}{\partial X^{2}} .\right.
\end{aligned}
$$

ここで $T$ は時刻， $X$ は長手方向の座標， $\rho_{m}$ は推進体密度， $A$ は断面積, $\eta$ は減衰定数, $E$ はヤング率, $I$ は断面二次モ 一メント, $H$ は振幅変位, $B$ は幅, $\Delta P$ は拱動流体圧, $M$ はアクチュエータの発生モーメント, [・] は推進体上での物 理量のジャンプ，〈•〉は推進体の $Z$ 軸方向での平均值を表 す.

\section{$2 \cdot 3$ アクチュエータシステムの同定}

SMAアクチュエータはヒステリシス特性を有する.そこ
で, 実験結果からアクチュエータ内部温度とアクチュエー タ・シリコーン複合体の発生モーメントの関係を調べ, こ れより非線形特性を Preisach モデルによりモデル化した。 この結果をFig. 3に示す.ただし，実線が計測データであり 破線が Genetic Programming (GP)により同定したモデルに よる結果である。

\section{3 実験結果}

Fig. 1の実験装置において, 移動平均のデー夕数を変化さ せながら空気中で発振させた時の末端部の振幅変位の計測 結果をFig. 4に示す.これより, 移動平均のデータ数を逐次 変更させることで柔軟に発振周波数を変更できることを確 認した。

\section{4 結言}

構築した解析モデルを元に, 自励駆動による推進体の評 価を行い推進体の製作を行った．製作した推進体は発振周 波数を柔軟に変更可能であることを確認した.

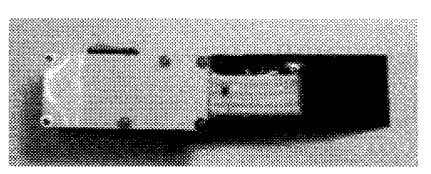

Fig. 1. Prototype of the moving body

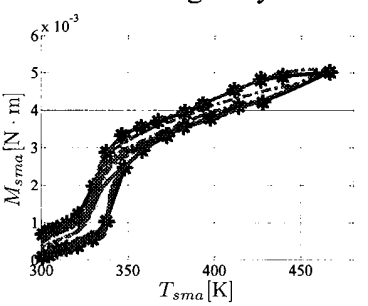

Fig. 3. Identified hysteretic characteristic of SMA

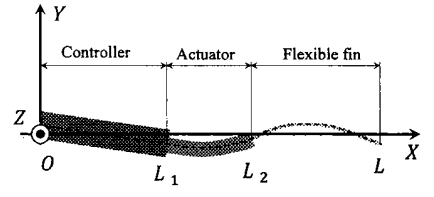

Fig. 2. Analytical model of the moving body

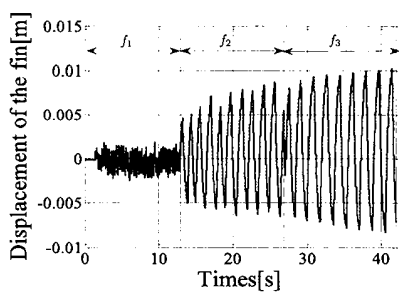

Fig. 4. Time history of displacement at the fin

\section{参考文献}

(1) Zhenlong Wang et al., "A micro-robot fish with embedded SMA wire actuated flexible biomimetic fin", Sensors and Actuators A 144, (2008), pp. 354-360.

(2) Guntis Kulikovskis et al., "Robotic Fish Tail Motion Excitation by Adaptive Control", Scientific Journal of Riga Technical University, Vol. 33, (2010), pp. 15-20.

(3) Olivier Doar'e et al., "Flutter of an elastic plate in a channel flow: confinement and finite-size effects. Journal of Fluids and Structures", Journal of Fluids and Structures, (2010), pp. 1-23. 